\title{
THE LITERARY LEGACY OF FRANCISK SKORINA ${ }^{1}$
}

\section{Abstract:}

The article assesses the value of the literary heritage of the doctor Francisk Skorina (16th century) and the distribution of publications of this great Belarusian educator in the Slavic world.

\section{Keywords:}

Francisk Skorina, Belarusian literature, biblical studies, Slavistics.

АННОтация: Ю.А. ЛАБЫНЦЕВ. «КНИЖНОЕ НАСЛЕДИЕ ФРАНЦИСКА СКОРИНЫ».

Статья посвящена оценке значения книжно-литературного наследия доктора наук Франциска Скорины (XVI в.) и распространению изданий этого великого белорусского просветителя в славянском мире.

\section{Ключевые слова:}

Франциск Скорина, белорусская литература, библеистика, славистика.

Zrancisк Skorina / in Bel. Francysк Skarina (approximately end of the 1480s,

Colotsk - post 1540, Prague) was an Eastern Slavic educator, humanist, publisher, translator, biblical scholar, doctor of medicine, and the national pride of the Belarusian people. The Bible published by him in his translation (The Russian Bible compiled by Dr. Francisk Skorina from the glorious city of Polotsk, for the honor of God and for the men of the Commonwealth for good knowledge) became the first printed Bible among the Eastern and South Slavic peoples. It was published almost half a century before the advent of Bibles printed in Polish.

He was born into a Belarusian merchant family in Polotsk, received his initial education at home and in local city schools. During his lifetime, Skorina traveled to many countries, studied at the oldest European universities, earned the highest academic degrees, was a doctor of "the seven free arts" (the liberal arts) and a doctor of medicine. Between 1504-06 he studied at the Krakow Academy, which awarded him a bachelor's degree on 14 December 1506, and in 1512 he received a doctorate in medicine from the University of Padua. During these years, under the influence of the ideas of the European Renaissance, Skorina conceived a grandiose undertaking: the publication of a Russian Bible itself. Between the years 1517-19, in Old Prague ("in the old city of Prague"), Skorina published 23 books of the Old Testament, translated by him into Russian, supplied with various kinds of commentaries, mainly in the form of voluminous forewords and

1 The work was carried out with the financial support of the RFBR (grant № 18-512-76004). 


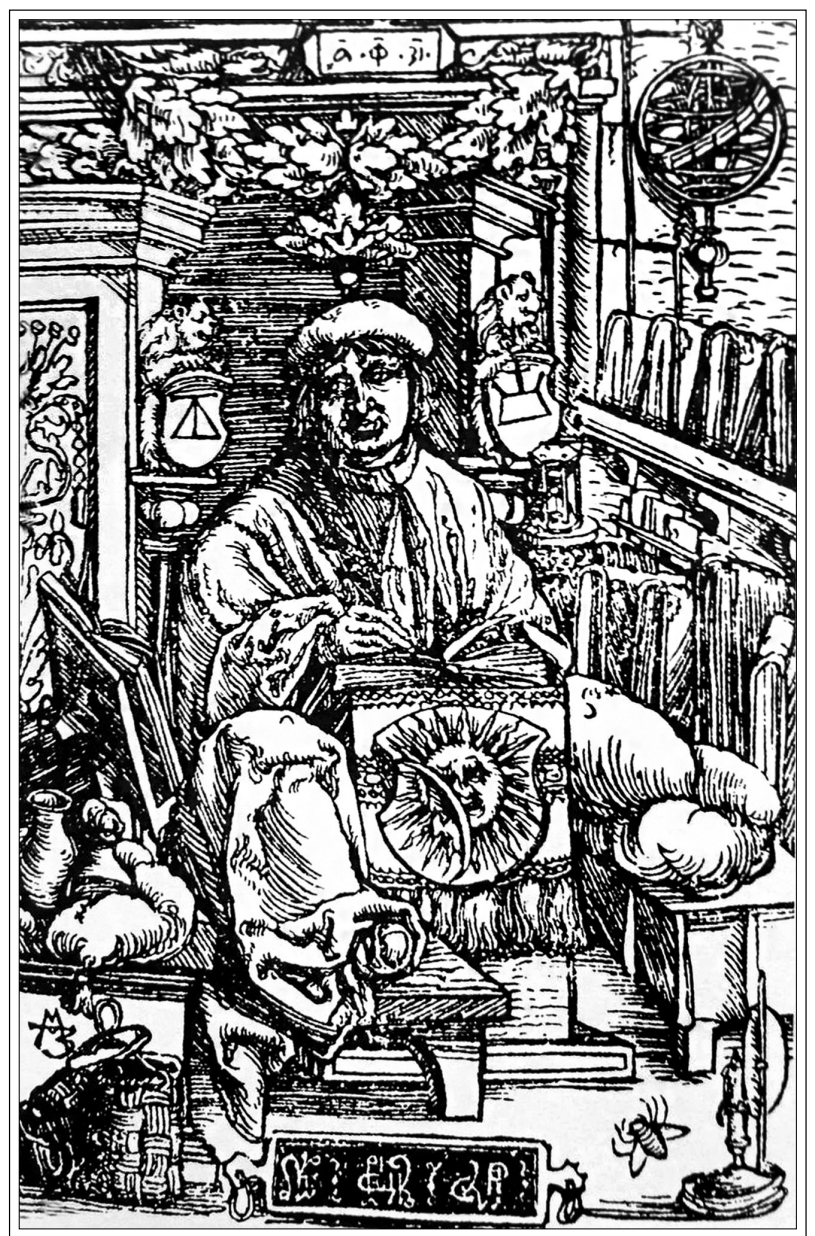

A portrait of Dr. Francisk Skorina.

Engraving. 1517

afterwords. In this publication, a xylographic portrait of Skorina himself was also placed, which was a unique phenomenon in the European publishing practice of that time. This publication was not completed: a number of the books of the Old Testament prepared by Skorina for publication unfortunately remained just in manuscript form.

In the early 1520s, Skorina passed through Breslau (Wroclaw) to the capital of the Grand Duchy of Lithuania, Russia and Zhemaitian Vilna (Vilnius), where he founded the first printing house in Eastern Europe. At the same time, Skorina most likely rented a Prague printing house, but he organized the Vilnius printing house himself. In Vilna he published more than 20 books, among which was a special collection, published about 1522, entitled The Small Road Book. This 
collection also contained a number of works by Skorina himself, including hymnographic ones. The final publication of the Vilnius printing house, The Apostle, was published in March 1525. In the second half of the 1520s. Skorina married Margarita (Malgorzata), the widow of a Vilna merchant, Yury Odvernik (Georgy Odvernikovich). In 1529 he traveled to Poznan' on business about the inheritance of his elder brother Ivan, who had died there.

The following year Skorina was in Königsberg at the court of the Prussian Duke Albrecht, who gave him special protection and called him "an outstanding learned man." These same qualities contributed to Skorina's serving for some time as the personal secretary and doctor of the Vilnius Catholic Bishop Jan. In the spring of 1532, Warsaw merchants Moses and Lazarus slandered Skorina, calling him "an idle man, a vagabond and indigent." As a result, he spent more than two months in a Poznan' prison, from which he was released by special decree of King Sigismund I as a slandered person. In the last years of his life, Skorina apparently lived in Prague, which is evidenced in particular by the charter of King Ferdinand I, issued on 29 January 1552 to Simeon Rus, in which his dead father Skorina appeared as "our gardener." The latter gives reason to consider Skorina as being one of the creators of the Royal Botanic Gardens, one of the first in Europe.

Skorina was a prominent figure of the European Renaissance, a pioneer of the Slavic Renaissance, the brightest representative of the Belarusian and all East Slavic cultures. A convinced humanist and educator, he strove all his life to serve his countrymen, first of all by giving them his own Bibliya Ruska and making the eternal biblical truths accessible even to "the ordinary people." Skorina's social ideal was: "Equal freedom for all, common property for all. According to this law everyone believing in Christ lives." The books Skorina published, including his voluminous "Bibliya Ruska," are the colossal work of a humanist and writer. His books represent a complex set of hundreds of different literary works written, translated or prepared by him for printing according to the strictest canons of

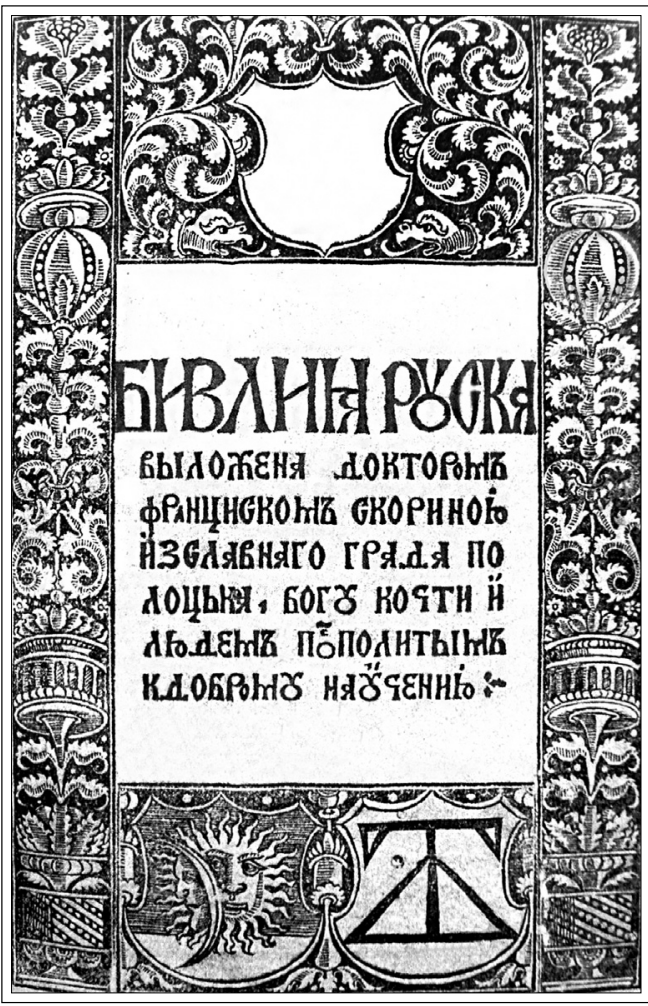

The title page of the publication by Francisk Skorina "Bibliya Ruska" ("The Russian Bible"). Prague, 1517-19 
publishing at that time. Skorina, as a master of words, appears before us at once in several guises: a prose writer, a hymnographer and a poet, an excellent translator from ancient and new languages. Skorina's work is a synthesis of old and new in Belarusian literature. Without the use of the old, classical tradition, without reliance on it, his compatriots simply would not have understood.

The essence of Skorina's literary feat lies in the fact that for the first time he succeeded in combining two major traditions of European culture - Eastern and Western - and introducing new literary forms. Such a synthesis by Skorina was a completely unique phenomenon, standing at the wellspring of a newly emerging East Slavic literature, worthy of being noted in all the annals of world literature. Skorina's literary and publishing activities were noticed by contemporary humanists: his books not only appeared in their personal libraries, but fragments were also reprinted by them. Skorina's distinction lies in the fact that his purpose was to make his publications and works available not to just a narrow circle of educated people but to all people without exception.

For this reason he did not write in the language of high Latin, but resorted to a language close to the people, and used traditional literary genres. Despite the non-canonical nature of the Bible translated and printed by him, it gained great popularity in Eastern Europe among Belarusians, Russians, Ukrainians and Slavs living along the ridges of the Carpathians. One can even speak of the direct influence of Skorina's Bible on Ukrainian literature (primarily Ukrainian Bible publications and manuscripts, including the New Testament). It also made wide inroads in the Moscow state and Russian lands. It was in the Russian lands that Skorina's works were destined for the longest life. Russian Old Believers, for example, copied and reprinted Skorina's texts (especially hymnographic) until the beginning of the 20th century.

On the whole, the literary, philosophical and theological heritage of Skorina, this recognized genius of the Slavic world as well as a source of pride and a symbol of Belarusian national culture, is still not well understood. However, what we do know about him is enough to understand the scale of his figure. It is not by chance that many Belarusian streets, avenues and educational institutions are named after Francisk Skorina. In Belarus', in honor of the educator, state "Skorina" awards were established, and monuments to him were erected not only at home, but also abroad.

Translated by Igor Kaliganov

\section{BIBLIOGRAPHY}

Nemirouskij EL. Francisk Skorina: Žizn' i deatel'nost' belorusskogo prosvetitelâ. Minsk, $1990.597 \mathrm{~s}$.

Labyncaŭ Ju. Pačataje Skarynam. Minsk, 1990. 333 s.

Halienčanka HJa. Francysk Skaryna - bielaruski i uschodnieslavianski pieršadrukar. Minsk, 1993. 280 s. 


\section{ILLUSTRATIONS}

1. Portrait of Dr. Francisk Skorina. Engraving, 1517.

2. The title page of the publication by Francisk Skorina Bibliya Ruska. Prague, 1517-19.

3. The first sheet of the translation by Francisk Skorina's the books of Jesus Sirakh. Prague, 1517.

4. The first sheet of the translation by Francisk Skorina The Song of Songs. Prague, 1518.

5. The first sheet of the translation by Francisk Skorina Ecclesiastes. Prague, 1518.

6. The last sheet of the translation by Francisk Skorina Ecclesiastes. Prague, 1518.

7. The first sheet of the translation by Francisk Skorina's the book of Judges. Prague, 1519.

8. The first sheet of the translation by Francisk Skorina's the book of Deuteronomy. Prague, 1519.

9. The first sheet of the translation by Francisk Skorina's the book of Esther. Prague, 1519. 